\title{
Corporate Social Responsibility dan Struktur Kepemilikan Serta Perannya terhadap Nilai Perusahaan
}

\begin{tabular}{|c|c|}
\hline \multirow{3}{*}{$\begin{array}{l}\text { Submitted Date : } \\
2 \text { July } 2021 \\
\text { Accepted Date : } \\
26 \text { August } 2021\end{array}$} & $\begin{array}{r}\text { Nurzanah Ma'rufa* } \\
\text { Universitas Pendidikan Indonesia, Bandung, Indonesia } \\
\text { nurzanahm@upi.edu }\end{array}$ \\
\hline & $\begin{array}{r}\text { Nugraha } \\
\text { Universitas Pendidikan Indonesia, Bandung, Indonesia } \\
\text { nugraha@upi.edu }\end{array}$ \\
\hline & $\begin{array}{r}\text { Maya Sari } \\
\text { Universitas Pendidikan Indonesia, Bandung, Indonesia } \\
\text { mayasari@upi.edu }\end{array}$ \\
\hline
\end{tabular}

Suggested Citation:

Abbott, L. J., Peters, G. F., \& Raghunandan, K. (2003). An empirical investigation of audit fees, non-audit fees, and audit committees. Contemporary Accounting Research, 20(2), 215-234.

Abstract:

Firm value is the perception of investors on the value of the company's performance and the company's prospects in the future. This study aims to determine the effect of corporate social responsibility and ownership structure on firm value. The research method used is the verification method. The objects in this study are non-state-owned basic and chemical industrial companies listed on the Indonesia Stock Exchange for the period 2010-2018 with a total of 46 companies and 414 observational data. The data analysis technique used in this research is piecewise linear regression. The results of the study state that corporate social responsibility has no significant effect on firm value, ownership structure has a nonlinear relationship with firm value, and the research model on the influence of corporate social responsibility and ownership structure on firm value which is controlled by firm size, profitability, and leverage can be used to explain or predict firm value. Corporate social responsibility and ownership structure have an indirect effect on firm value.

Keywords: Corporate Social Responsibility; Firm Value; Ownership Structure

Abstrak

Nilai perusahaan merupakan persepsi dari investor terhadap nilai dari kinerja perusahaan dan prospek peusahaan di masa mendatang. Penelitian ini bertujuan untuk mengetahui pengaruh corporate social responsibility dan struktur kepemilikan terhadap nilai perusahaan. Metode penelitian yang digunakan adalah metode verifikatif. Objek pada penelitian ini adalah perusahaan industri dasar dan kimia Non-BUMN yang terdaftar di Bursa Efek Indonesia periode tahun 2010-2018 dengan total 46 perusahaan dan 414 data observasi. Teknik analisis data yang digunakan dalam penelitian ini adalah piecewise linear regression. Hasil penelitian menyatakan bahwa corporate social responsibility berpengaruh tidak signifikan terhadap nilai perusahaan, struktur kepemilikan memiliki hubungan berbentuk nonlinier dengan nilai perusahaan, dan model penelitian pengaruh corporate social responsibility dan struktur kepemilikan terhadap nilai perusahaan yang dikontrol oleh ukuran perusahaan, profitabilitas, serta leverage dapat digunakan untuk menjelaskan atau memprediksi nilai perusahaan. Corporate social responsibility dan struktur kepemilikan berpengaruh secara tidak langsung terhadap nilai perusahaan.

Kata Kunci: Corporate Social Responsibility; Nilai Perusahaan; Struktur Kepemilikan

Klasifikasi JEL: G32

${ }^{*}$ Corresponding Author 


\section{Latar Belakang}

Nilai perusahaan merupakan persepsi dari investor terhadap nilai dari kesuksesan perusahaan yang tercermin pada harga saham (Keown et al., 2010; Harmono, 2011; Margaretha, 2011). Indeks Harga Saham Gabungan (IHSG) atau Jakarta Composite Index adalah indeks dari seluruh saham yang diperdagangkan di Bursa Efek Indonesia (BEI). Pergerakan IHSG dari sembilan sektor di BEI pada periode 28 Juni 2019 - 30 Juni 2020 dapat terlihat dalam gambar 1.

Gambar 1 Jakarta Composite Index dan Sectoral Indices Movement

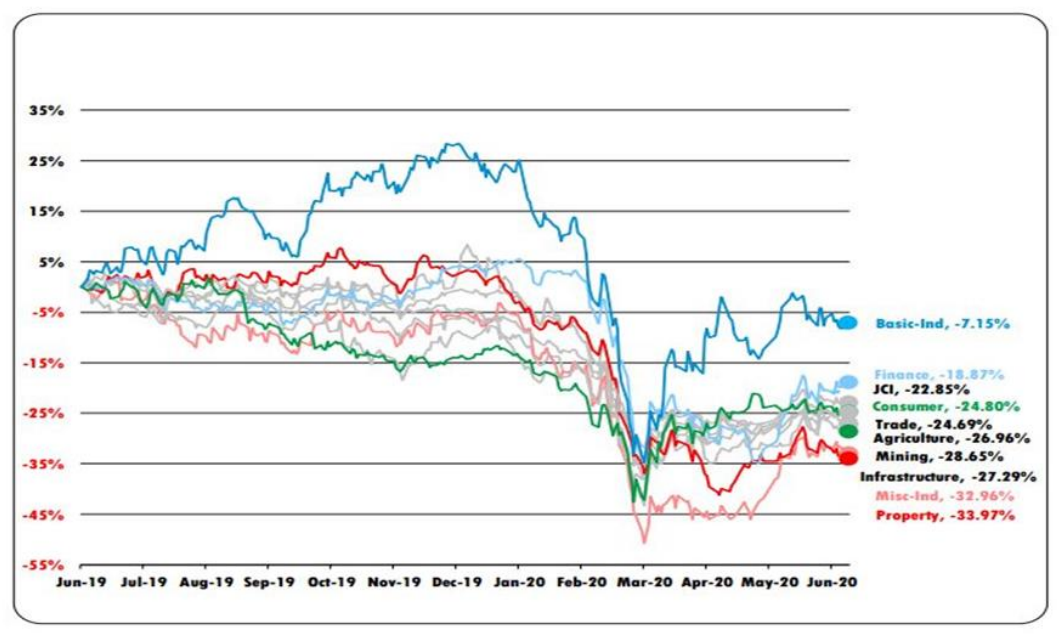

Sumber: Bursa Efek Indonesia (2020)

Dengan melihat grafik 1 maka dapat disimpulkan bahwa terjadi fluktuasi yang cenderung menurun pada rata-rata IHSG semua sektor di BEl. Jika dilihat pada grafik 1 perusahaan industri dasar dan kimia dengan mengabaikan dampak negatif dari kemunculan COVID-19 pada bulan Maret 2020 memiliki pergerakan IHSG yang paling baik dibandingkan dengan sektor lainnya. Mengapa hal tersebut dapat terjadi merupakan fenomena yang menarik untuk diteliti. Tabel 1 menyajikan presentase kenaikan dan penurunan nilai perusahaan pada perusahaan industri dasar dan kimia di BEl tahun 2010-2018 yang diproksikan oleh PBV (price book value).

Tabel 1 Kenaikan dan Penurunan PBV Industri Dasar dan Kimia

\begin{tabular}{rrr} 
Tahun & Rata-Rata PBV & \multicolumn{1}{c}{$\begin{array}{l}\text { Kenaikan/ } \\
\text { Penurunan }\end{array}$} \\
\hline 2010 & 1,585208 & \\
2011 & 1,673542 & $5,57 \%$ \\
2012 & 1,818333 & $8,65 \%$ \\
2013 & 1,369167 & $-24,70 \%$ \\
2014 & 1,338542 & $-2,24 \%$ \\
2015 & 0,975 & $-27,16 \%$ \\
2016 & 1,376875 & $41,22 \%$ \\
2017 & 2,861042 & $107,79 \%$ \\
2018 & 1,794375 & $-37,28 \%$ \\
\hline
\end{tabular}

Sumber: Data Diolah (2020)

Tabel 1 menunjukkan bahwa terjadi fluktuasi yaitu peningkatan dan penurunan yang tidak stabil nilai perusahaan industri dasar dan kimia di BEI periode tahun 2010-2018. Namun, jika dilihat presentase kenaikan yang terjadi lebih besar dibandingkan presentase penurunannya. Dapat disimpulan bahwa penurunannya berbanding jauh dengan kenaikannya yang tinggi. Pergerakan nilai perusahaan industri dasar dan kimia di $\mathrm{BEI}$ periode tahun 2010-2018 memiliki tendensi yang baik.

Perusahaan dituntut terus meningkatkan kinerja untuk dapat mempertahankan kelangsungan usahanya dan untuk dapat memenangkan persaingan bisnis yang semakin ketat. Indikator yang sering digunakan untuk menilai kinerja perusahaan ialah tingkat pengembalian (return) terhadap pemilik dan nilai perusahaan. Jadi, secara ideal nilai perusahaan diharapkan meningkat. Fenomena nilai perusahaan yang menunjukkan tendensi yang baik (meningkat) atau tendensi yang buruk (menurun) menjadi fenomena menarik yang perlu diteliti. 
Mengapa hal tersebut terjadi menjadi latar belakang penelitian. Menurut Husnan \& Pudjiastuti (2012) semakin tinggi nilai perusahaan semakin besar kemakmuran yang akan diterima oleh pemilik perusahaan.

Penelitian ini mengkaji nilai perusahaan pada perusahaan-perusahaan sektor industri dasar dan kimia, yang terdiri dari sub sektor semen; kayu \& pengolahannya; keramik, porselen, \& kaca; plastik \& kemasan; bubur kertas \& kertas; kimia; logam \& sejenisnya; pakan ternak; serta lainnya. Periode penelitian dalam penelitian ini yaitu tahun 2010-2018. Pemilihan periode penelitian dimulai pada tahun 2010 dikarenakan pertimbangan menghindari dampak perekonomian Indonesia yang mengalami tekanan yang cukup berat pada saat krisis keuangan global (Global Financial Crisis/GFC) 2008-2009.

Teori keagenan digunakan pada penelitian ini untuk menjawab faktor yang mempengaruhi nilai perusahaan. Corporate Social Responsibility (CSR) sebagai asuransi bagi perusahaan agar para stakeholder mempercayai perusahaan (manajemen) sehingga meningkatkan kontribusinya pada perusahaan. Sedangkan, berdasarkan pandangan pemegang saham CSR dianggap sebagai penyalahgunaan biaya atas dampak sifat opportunistic dari manajemen, yang tentu merugikan pemegang saham. Tidak adanya pemisahan kepemilikan antara manajemen dengan pemegang saham maka akan meningkatkan kepercayaan pemegang saham pada manajemen karena sifat opportunistic dari manajemen dianggap hilang. Manajer memiliki tujuan yang sama untuk meningkatkan nilai perusahaan. Oleh karena itu, CSR dan struktur kepemilikan memiliki kedudukan yang sama terkait hubungannya pada nilai perusahaan, yang didasarkan pada teori keagenan keduanya memiliki keterikatan satu sama lain untuk mempengaruhi nilai perusahaan.

Teori stakeholder yang dinyatakan oleh Chariri \& Ghozali (2007), yaitu bahwa perusahaan bukanlah entitas yang hanya beroperasi untuk kepentingan shareholder saja namun telah bergeser menjadi lebih luas yaitu perusahaan juga harus memberikan manfaat bagi para stakeholder. Stakeholder theory berpendapat bahwa CSR memiliki hubungan positif pada kekayaan pemegang saham (nilai perusahaan) karena fokus pada kepentingan pemangku kepentingan lain yang meningkatkan kesediaan mereka untuk mendukung operasi perusahaan. Argumen ini sejalan dengan contract theory, yang memandang perusahaan sebagai hubungan kontrak antara pemegang saham dan pemangku kepentingan lain yang memasok sumber daya kritis. Kontrakkontrak ini bisa dalam bentuk eksplisit atau implisit, dan perusahaan dapat secara default terikat pada kontrak implisit. Nilai kontrak ini tergantung pada harapan para pemangku kepentingan atas perusahaan untuk menghormati komitmennya. Hal tersebut konsisten dengan CSR yang menyediakan asuransi ex-post. Godfrey et al. (2009) menunjukkan bahwa CSR mengurangi sanksi pemangku kepentingan setelah tindakan hukum atau peraturan. Paparan yang dirasakan perusahaan terhadap penurunan risiko dihargai oleh investor (Boyer et al., 2009; Conrad et al., 2013). Investor hargai mekanisme yang mengurangi eksposur perusahaan terhadap penurunan risiko (Allayannis \& Weston, 2001; Pérez-González \& Yun, 2013). Oleh karena itu, CSR meningkatkan nilai perusahaan dengan meningkatkan hubungan perusahaan dengan kelompok pemangku kepentingan.

Namun, pandangan biaya pemegang saham menunjukkan bahwa CSR dilakukan dengan mengorbankan pemegang saham dan oleh karena itu, menurunkan nilai perusahaan (Friedman, 1970; Friedman, 1998; Pagano \& Volpin, 2005; Cronqvist et al., 2009). Friedman (1998) mengemukakan bahwa keberadaan CSR adalah semata sebagai manifestasi dari masalah keagenan. Perspektif agency theory menyiratkan pengeluaran biaya CSR adalah penyalahgunaan dana yang harus digunakan untuk proyek yang menambah nilai pemegang saham, dan bahwa pengeluaran biaya CSR adalah kegiatan eksekutif (McWilliams et al., 2006).

Kesimpulannya adalah bahwa terjadi gap empiris terkait hubungan antara CSR dan nilai perusahaan. Berdasarkan stakeholder theory, contract theory, dan signaling theory serta beberapa penelitian terdahulu bahwa CSR memiliki hubungan positif dengan nilai perusahaan. Hal tersebut dikarenakan CSR meningkatkan hubungan antara perusahaan dan kelompok pemangku kepentingan yang berkonstribusi terhadap perusahaan. Namun, berdasarkan teori keagenan dan pendapat lain menyatakan bahwa CSR berpengaruh negatif terhadap nilai perusahaan. Biaya CSR adalah penyalahgunaan dana yang seharusnya dialokasikan untuk menambah proyek yang dapat meningkatkan nilai perusahaan. CSR adalah biaya yang dikeluarkan dan diperuntukkan mendukung kepentingan pihak manajemen. Misalnya, meningkatkan alokasi pembiayaan asuransi kesehatan sehingga bentuk asuransi kesehatan yang akan diterima oleh pihak manajemen juga akan lebih baik. Selain itu, terdapat perbedaan hasil penelitian antara CSR dan nilai perusahaan dengan sebagian besar studi menunjukkan hubungan positif (Garcia-Castro et al.,2010). Beberapa lainnya menemukan hubungan negatif (Bhandari \& 
Javakhadze, 2017) dan hasil penelitian yang menyatakan bahwa CSR tidak memiliki hubungan dengan nilai perusahaan (McWilliams \& Siegel, 2000).

Dalam penelitian ini stakeholder theory dan teori sinyal digunakan untuk menjelaskan hubungan CSR dan nilai perusahaan. Memaksimalkan kekayaan pemegang saham tidak berarti bahwa manajemen harus mengabaikan CSR, seperti melindungi konsumen, membayar upah yang adil kepada karyawan, mempertahankan praktik perekrutan yang adil dan kondisi kerja yang aman, mendukung pendidikan, serta terlibat dalam masalah lingkungan seperti udara bersih dan air. Manajemen perlu mempertimbangkan kepentingan pemangku kepentingan selain pemegang saham. Pemangku kepentingan tersebut meliputi kreditor, karyawan, pelanggan, pemasok, komunitas di mana suatu perusahaan beroperasi, dan lainnya. Dengan menciptakan nilai tambah bagi pelanggan, perusahaan dapat menaikkan harga dan meningkatkan laba. Membuat keputusan yang menguntungkan karyawan (misalnya, meningkatkan keamanan kerja mereka) dapat menawarkan upah yang lebih rendah atau mendapatkan keuntungan dari peningkatan produktivitas. Namun, jika pelanggan atau karyawan mengantisipasi bahwa perusahaan kemungkinan besar akan mengeksploitasi mereka maka pelanggan atau karyawan akan menuntut harga yang lebih rendah atau upah yang lebih tinggi.

Sebagai sinyal karakter perusahaan, kecenderungan perilaku dan nilai-nilai perusahaan, CSR membangun niat baik dengan para pemangku kepentingan. Niat baik ini memberikan perlindungan seperti asuransi bagi perusahaan dengan mengurangi reaksi pemangku kepentingan terhadap peristiwa negatif (peristiwa dengan konsekuensi negatif bagi pemangku kepentingan di mana motivasi yang mendasari untuk peristiwa ini dianggap berasal dari manajerial yang hanya mementingkan dirinya pribadi). Untuk perusahaan dengan kredensial CSR yang kuat, para pemangku kepentingan cenderung kurang untuk menghubungkan peristiwa negatif dengan niat jahat dari pihak perusahaan dan karenanya cenderung untuk tidak menjatuhkan hukuman berat. CSR berkontribusi untuk meningkatkan reputasi perusahaan dalam menjaga komitmennya, dan karenanya meningkatkan insentif para pemangku kepentingan berkontribusi untuk perusahaan. Sektor industri dasar dan kimia, salah satu industri manufaktur, tentu menghasilkan limbah produksi. Jika perusahaan tidak memiliki kepedulian terhadap pengelolaan limbah atau tidak melaporkan kepeduliaan pengelolaan limbah pada laporan tahunan maka dampak buruk akan terjadi pada perusahaan di masa mendatang. Oleh karena itu, CSR dalam pengaruhnya terhadap nilai perusahaan, khususnya pada industri dasar dan kimia, menjadi perhatian penting dalam penelitian.

Selanjutnya, manajer mendasarkan keputusan investasi pada informasi yang sulit untuk diamati investor luar. Akibatnya, manajer tidak selalu mengalokasikan sumber daya perusahaan dengan cara yang dapat memaksimalkan kekayaan pemegang saham. Masalah mengamati kesempatan investasi perusahaan dapat menyebabkan konflik keagenan pemegang saham dan manajer (Jensen, 1986). Konflik kepentingan dan pertimbangan etika muncul ketika beberapa pemangku kepentingan di perusahaan mendapatkan keuntungan dan kerugian lain dari suatu keputusan (Berk et al., 2012). Kepemilikan manajerial dapat menghasilkan insentif yang berkontribusi terhadap agen dalam penyelesaian konflik (Jensen \& Meckling, 1976; O'Sullivan, 2000; Larcker \& Richardson, 2004; Desender et al., 2013). Meningkatkan kepemilikan manajerial dalam bentuk saham dan opsi mengarah pada peningkatan sensitivitas kekayaan manajerial terhadap harga saham. Delta yang lebih tinggi menyelaraskan perilaku manajerial dengan kepentingan pemegang saham, sehingga mendorong manajer untuk bekerja lebih keras dan mengambil proyek berisiko yang meningkatkan nilai (Jensen \& Meckling, 1976; Myers, 1977; Haugen \& Senbet, 1981). Investor luar merasakan bahwa manajer dengan aksi kepemilikan saham besar memaksimalkan nilai perusahaan dan kinerjanya (Fan \& Wong, 2002; Abbott et al., 2003).

Namun, peningkatan kepemilikan manajerial memfasilitasi pengukuhan yang lebih dalam yang dapat menyebabkan keputusan manajerial yang meningkatkan kekayaan pribadi manajemen melalui pengambilalihan pemegang saham minoritas (Schleifer \& Vishny, 1997; Morck et al., 1988; Himmelberg et al., 1999; Ho \& Wong, 2001). Morck et al. (1988) menemukan bahwa kepemilikan manajerial secara positif terkait dengan kinerja perusahaan sampai manajemen memiliki perusahaan, sekitar $5 \%$, dan pada tingkat kepemilikan manajerial diatas $25 \%$, karena minat manajer disesuaikan dengan kepentingan pemegang saham. Sebaliknya, kepemilikan saham manajer berbanding terbalik dengan kinerja sekitar 5-25\% kepemilikan manajerial (Morck et al., 1988). Temuan Morck et al. (1988) didukung dalam banyak penelitian lain (McConnel \& Servaes, 1990; Schooley \& Barney, 1994; Kole, 1995; Holderness et al., 1999; Short \& Keasey, 1999; Miguel et al., 2004; Davies et al., 2005).

Gap empiris yang terjadi terkait hubungan SK-NP adalah menurut Jensen \& Meckling (1976) yaitu bahwa struktur kepemilikan berpengaruh positif terhadap nilai perusahaan. Hal tersebut dikarenakan kepemilikan manajerial dianggap dapat menyelaraskan kepentingan antara pihak manajemen dengan para pemegang saham. Sehingga peningkatan nilai perusahaan juga diharapkan oleh manajer. Sedangkan, temuan Morck et al. 
(1988) menyatakan bahwa struktur kepemilikan berpengaruh secara nonlinier berbentuk U terbalik terhadap nilai perusahaan. Menurut Morck et al. (1988) kepemilikan manajerial berpengaruh positif terhadap nilai perusahaan pada level kepemilikan rendah dan tinggi. Hal tersebut dikarenakan pada level kepemilikan manajerial tertentu konflik keagenan akan hilang, namun konflik antara pemegang saham kecil dan besar terjadi.

Penyelarasan kepentingan antara manajer dan pemegang saham dijelaskan oleh hipotesis konvergensi kepentingan, yaitu bahwa manajer memposisikan dirinya sama seperti pemilik perusahaan. Selain implikasi hipotesis konvergensi kepentingan, pertimbangan hipotesis management entrenchment juga berguna karena meningkatkan pemahaman saat ini tentang implikasi kepemilikan manajerial untuk perilaku manajemen dan insentif yang mendasarinya. Hipotesis management entrenchment menunjukkan bahwa pada tingkat tertentu atas kepemilikan manajerial, manajemen memiliki kekuatan suara yang cukup atau kontrol dewan, hal tersebut ditujukan untuk melindungi posisi mereka atas tindakan disipliner dari dewan atau pasar tenaga kerja, bahkan ketika kinerjanya jatuh di bawah tingkat yang dapat diterima. Kondisi ini terjadi ketika kepemilikan manajer berada pada presentase 5\%-25\%. Dengan demikian, hipotesis entrenchment memprediksi hubungan negatif antara struktur kepemilikan dan nilai perusahaan. Efek insentif yang saling bertentangan antara hipotesis konvergensi kepentingan dan hipotesis entrenchment mengarahkan hubungan nonlinear antara SK-NP. Perbedaan yang diperhatikan dalam penelitian ini, yaitu bahwa perusahaan BUMN memberikan batasan kepada berapa persen saham dimiliki oleh seseorang, kepemilikan terbesar masih dimiliki oleh Negara Republik Indonesia. Oleh karena itu, penelitian hanya dilakukan pada perusahaan industri dasar dan kimia yang merupakan perusahaan BUMS.

Variabel kontrol yang sering digunakan dalam penelitian terdahulu terkait hubungan terhadap nilai perusahaan, juga digunakan dalam penelitian ini diantaranya adalah ukuran perusahaan, profitabilitas, serta leverage. Sheikh (2018) dan Rjiba et al. (2020) dengan penelitiannya terkait hubungan antara CSR dengan firm value menggunakan $R O A$, sales, leverage, $R \& D$, capital expenditures, size, dan/atau market to book ratio sebagai variabel kontrol. Selanjutnya, hubungan kepemilikan manajerial dengan nilai perusahaan dalam penelitian Benson et al. (2019) dikontrol oleh variabel earnings announcement standard deviation, size, market to book dispersion, ceo turnover, ebitda/sales, incentive pay proportion, information asymmetry, investment opportunity set, tangible assets, free cash flow, dan/atau capital structure.

Adapun tujuan dari penelitian ini adalah untuk mengetahui pengaruh CSR terhadap nilai perusahaan pada perusahaan industri dasar dan kimia Non-BUMN di BEl. Selanjutnya, untuk mengetahui pengaruh struktur kepemilikan terhadap nilai perusahaan pada perusahaan industri dasar dan kimia Non-BUMN di BEI. Terakhir, untuk mengetahui pengaruh CSR dan struktur kepemilikan terhadap nilai perusahaan yang dikontrol oleh ukuran perusahaan, profitabilitas, serta leverage pada perusahaan industri dasar dan kimia Non-BUMN di BEI.

\section{Metode Penelitian}

Metode penelitian yang digunakan adalah metode verifikatif, untuk menguji hipotesis dalam penelitian ini. Nilai perusahaan diukur dengan menggunakan PBV, yaitu perbandingan antara harga saham dengan nilai bukunya. Sedangkan CSR diukur dengan perbandingan antara total skor pengungkapan CSR setiap perusahaan pada setiap tahunnya dengan 91 item CSRI GRI G4. Selanjutnya, strukur kepemilikan diukur dengan menggunakan presentase saham yang dimiliki oleh pihak manajemen perusahaan yang secara aktif ikut serta dalam pengambilan keputusan perusahaan (komisaris dan direksi). Penentuan sampel dilakukan secara non probalilitas (nonprobability sampling) dengan metode purposive sampling yang dilakukan dengan mengambil sampel dari populasi didasarkan pada suatu kriteria tertentu.

Tabel 2 Prosedur Pemilihan Sampel

\begin{tabular}{clrc}
\hline No. & \multicolumn{1}{|c|}{ Keterangan } & Jumlah \\
1. & Perusahaan industri dasar dan kimia Non-BUMN di BEI & 75 \\
2. & $\begin{array}{l}\text { Perusahaan yang tidak mempublikasikan laporan tahunan selama periode } \\
\text { pelaporan 2010-2018 }\end{array}$ & 29 \\
& & Total Sampel & 46 \\
\hline
\end{tabular}

Sumber: www.idx.co.id, data diolah

Data yang digunakan dalam penelitian ini adalah data sekunder yang diperoleh dari Indonesia Stock Exchange (IDX) yang diakses melalui www.idx.co.id berupa laporan tahunan perusahaan. Oleh karena itu, teknik 
pengumpulan data yang digunakan dalam penelitian ini adalah teknik dokumentasi. Teknik analisis data yang digunakan dalam penelitian ini adalah regresi linier data panel berdasar pada piecewise linear regression yang dilakukan oleh Morck et al. (1988) dan McConnell \& Servaes (1990). Penelitian ini menggunakan tiga titik balik untuk menemukan slope yang mencerminkan perubahan perilaku struktur kepemilikan dari mendukung convergence of interest hypothesis kepada entrenchment hypothesis atau sebaliknya.

Hasil

Sebelum melakukan pengujian dengan model regresi data panel, terlebih dahulu perlu dilakukan pemilihan model estimasi regresi dengan data panel yang sesuai dengan data panel dalam penelitian ini. Pengujian untuk menentukan model regresi yang sesuai yang perlu dilakukan diantaranya adalah Uji Chow, Uji Hausman, dan Uji Langerange Multiplier (LM). Berikut hasil pengujian penentuan model estimasi regresi data panel.

Tabel 3 Uji Chow

\begin{tabular}{lrrr}
\hline Effects Test & Statistic & d.f. & Prob. \\
\hline Cross-section F & 2.627027 & $(45,361)$ & 0.0000 \\
Cross-section Chi-square & 117.275415 & 45 & 0.0000 \\
\hline
\end{tabular}

Sumber : Data Diolah (2020)

Output hasil uji chow menunjukkan bahwa $p$-value F-test sebesar $0,00<0,05$ sehingga model fixed effect lebih baik dibandingkan model common effect. Tabel 4 merupakan hasil uji hausman.

Tabel 4 Uji Hausman

\begin{tabular}{lrrr}
\hline Test Summary & Chi-Sq. Statistic & Chi-Sq. d.f. & Prob. \\
Cross-section random & 5.643970 & 7 & 0.5819 \\
\hline
\end{tabular}

Sumber : Data Diolah (2020)

Berdasarkan hasil uji hausman dapat dilihat bahwa $p$-value $0,5819>0,05$, sehingga model random effect lebih baik dari model fixed effect. Berdasarkan hasil uji chow dan hausman maka tidak perlu dilakukan uji LM. Model regresi data panel yang paling tepat digunakan dalam penelitian ini adalah random effect. Perbedaan antar individu dan/atau waktu diakomodasi lewat error pada random effect model, memperhitungkan bahwa error mungkin berkorelasi sepanjang time series dan cross section. Menurut Gujarati \& Porter (2009) estimasi model panel pengaruh acak (random effect) menggunakan metode Generalized Least Square (GLS).

Selanjutnya, untuk menguji robustness dari model piecewise linear regression maka dilakukan analisis pengujian regresi data panel tanpa melakukan pengujian sepotong demi sepotong. Dengan melihat $R$-squared model piecewise linear regression yang lebih tinggi dibandingkan dengan model regresi linier data panel yang tidak melakukan pengujian regresi sepotong demi sepotong, yaitu 0,310586 $>0,292532$. Ditambah dengan mempertimbangkan signifikansi koefisien regresi masing-masing variabel maka model persamaan regresi linier data panel yang digunakan dalam penelitian ini adalah model piecewise linear regression. Tabel 5 merupakan hasil analisis pengujian piecewise linear regression dengan menggunakan pendekatan random effect method.

Tabel 5 Uji Regresi Linier Data Panel Pendekatan Random Effect Method

\begin{tabular}{crrrr} 
Variabel & Coefficient & Std. Error & t-Statistic & \multicolumn{1}{c}{ Prob. } \\
C & $-2,392$ & 2,562 & $-0,933$ & 0,351 \\
CSR & 3,035 & 3,629 & 0,836 & 0,403 \\
MO0TO5 & $-0,183$ & 0,146 & $-1,254$ & 0,210 \\
MO5TO25 & 0,211 & 0,060 & 3,482 & 0,001 \\
MO25TO100 & $-0,106$ & 0,055 & $-1,927$ & 0,054 \\
FS & 0,198 & 0,168 & 1,183 & 0,237 \\
ROA & 0,053 & 0,017 & 3,013 & 0,002 \\
DER & 0,182 & 0,014 & 12,26 & 0,000 \\
Reighted Statistics & & \\
Adjusted R-squared & 0,310 & Mean dependent var & & 0,955 \\
S.E. of regression & 0,298 & S.D. dependent var & & 3,535 \\
F-statistic & 2,960 & Sum squared resid & & 3558,203 \\
Prob(F-statistic) & 26,129 & Durbin-Watson stat & & 2,045 \\
\hline
\end{tabular}

Sumber : Data Diolah (2020) 
Dari hasil pengujian diperoleh bahwa nilai $F_{\text {hitung }}>$ nilai $F_{\text {tabel, }}$ yaitu 26,12936 $>2,03214$ dengan tingkat signifikansi kurang dari $5 \%$. Hal tersebut menunjukkan bahwa model regresi yang diestimasi dalam penelitian ini berarti. Sehingga, model regresi dalam penelitian ini dapat digunakan untuk membuat kesimpulan. Adapun hasil uji t adalah sebagai berikut:

Tabel 6 Keputusan Hasil Uji t

\begin{tabular}{lrrrl}
\multicolumn{1}{c}{ Variabel } & \multicolumn{1}{c}{ thitung } & \multicolumn{1}{c}{ tabel } & \multicolumn{1}{c}{ Sig. } & Keputusan \\
\hline CSR & 0,836 & 1,965 & 0,403 & Ho diterima \\
MO0TO5 & $-1,254$ & $-1,965$ & 0,210 & $H_{0}$ diterima \\
MO5TO25 & 3,482 & 1,965 & 0,001 & $H_{1}$ diterima \\
MO25TO100 & $-1,927$ & $-1,965$ & 0,054 & $H_{0}$ diterima \\
\hline
\end{tabular}

Sumber : Data Diolah (2020)

Berdasarkan hasil tersebut, dapat disimpulkan bahwa :

1. CSR berpengaruh tidak signifikan terhadap nilai perusahaan.

2. Struktur kepemilikan $\leq 5 \%$ berpengaruh tidak signifikan terhadap nilai perusahaan.

3. Struktur kepemilikan 5\%-25 berpengaruh positif signifikan terhadap nilai perusahaan.

4. Struktur kepemilikan $>25 \%$ berpengaruh tidak signifikan terhadap nilai perusahaan.

\section{Pembahasan}

\section{Pengaruh Corporate Social Responsibility dan Struktur Kepemilikan Terhadap Nilai Perusahaan}

Ditemukan nilai $R$-squared pada penelitian ini adalah sebesar 0,310586 yang menunjukkan nilai perusahaan dipengaruhi oleh variabel CSR, struktur kepemilikan, ukuran perusahaan, profitabilitas, serta leverage sebesar $31,06 \%$. Sedangkan, sebesar $68,94 \%$ nilai perusahaan dipengaruhi oleh variabel lain selain variabel CSR, struktur kepemilikan, ukuran perusahaan, profitabilitas, dan leverage. Hasil penelitian ini mendukung penelitian Sudarma \& Darmayanti (2017) pada perusahaan sektor pertambangan di Indeks Kompas 100 dengan model penelitian pengaruh CSR, struktur kepemilikan, dan profitabilitas terhadap nilai perusahaan menunjukkan bahwa uji kecocokan model tersebut dapat diterima. R-squared penelitian Sudarma \& Darmayanti (2017) adalah sebesar $31,40 \%$, tidak memiliki selisih yang besar dengan model penelitian ini.

\section{Pengaruh Corporate Social Responsibility Terhadap Nilai Perusahaan}

Berdasarkan hasil uji keberartian koefisien regresi, CSR berpengaruh tidak signifikan pada nilai perusahaan. Hal ini memiliki arti bahwa setiap kenaikan atau penurunan dari pelaksanaan dan/atau pengungkapan CSR tidak akan mempengaruhi nilai perusahaan secara signifikan. Hasil penelitian ini tidak sejalan dengan teori rujukan yaitu teori sinyal yang menyatakan bahwa CSR merupakan sinyal perusahaan telah bertanggung jawab secara sosial terhadap stakeholder, yang nantinya akan berkonstribusi terhadap perusahaan sehingga akan meningkatkan nilai perusahaan.

Kondisi tersebut terjadi karena secara rata-rata pelaksanaan CSR pada perusahaan industri dasar dan kimia Non-BUMN di BEI hanya sebesar $15,80 \%$. Presentase rata-rata yang sangat kecil mengindikasikan bahwa perusahaan belum memaksimalkan pengungkapan dan/atau pelaksanaan CSR. Selain itu, beberapa penelitian terdahulu menyatakan bahwa CSR berpengaruh secara tidak langsung terhadap nilai perusahaan. Van \& Gossling (2008) menyatakan bahwa variabel industri, R\&D, dan risiko menjadi variabel penting yang mempengaruhi hubungan antara CSR-NP. Pernyataan tersebut didukung oleh McWilliams \& Siegel (2000) yang menyatakan bahwa sulitnya memahami dampak CSR pada kinerja tanpa melibatkan variabel R\&D. Selain itu, penelitian Orlitzky et al. (2003) menyatakan bahwa reputasi tampaknya menjadi mediator penting bagi hubungan CSR-NP. Buchanan et al. (2018) menemukan bahwa pengaruh CSR pada nilai perusahaan bervariasi dengan tingkat kepemilikan institusional yang berpengaruh dan tergantung pada kondisi ekonomi. Sehingga hubungan CSR-NP di Indonesia memiliki pola yang sama dengan penelitian yang berada di beberapa Negara lainnya, yaitu bahwa penelitian terkait hubungan CSR-NP tidak dapat mengabaikan variabel moderasi dan/atau intervening. Oleh karena itu, kita tidak dapat mengabaikan variabel tersebut dalam penelitian CSR-NP. Hubungan CSR-nilai perusahaan di Indonesia tidak memiliki kecenderungan tertentu (Rahmawati dkk., 2020). Hal tersebut 
dikarenakan sedikitnya penelitian di Indonesia terkait hubungan CSR-nilai perusahaan yang dilakukan tahun 2008-2018 dengan mempertimbangkan penggunaan variabel anteseden dan konsekuensi bersamaan dalam penelitian.

Hasil penelitian ini mendukung penelitian McWilliams \& Siegel (2000) dengan periode tahun penelitian 1991-1996 pada perusahaan di Amerika Serikat yang menunjukkan efek netral CSR terhadap nilai perusahaan. Sedangkan, penelitian ini memiliki perbedaan kesimpulan dengan beberapa penelitian lainnya yaitu, penelitian Garcia-Castro et al. (2010) dengan periode tahun penelitian 1991-2005 pada perusahaan yang termasuk dalam database KLD, penelitian Chang et al. (2019) dengan periode penelitian tahun 2010-2014 pada perusahaan di 40 Negara, penelitian Zolotoy et al. (2019) pada perusahaan di Amerika Serikat, penelitian Rjiba et al. (2020) dengan periode penelitian tahun 2002-2016 pada perusahaan di 36 Negara menunjukkan bahwa CSR berpengaruh positif terhadap nilai perusahaan, serta penelitian Bhandari \& Javakhadze (2017) dengan periode tahun penelitian 1992-2014 pada perusahaan di Amerika Serikat memberikan kesimpulan bahwa efek negatif terjadi pada hubungan CSR dan nilai perusahaan.

\section{Pengaruh Struktur Kepemilikan Terhadap Nilai Perusahaan}

Berdasarkan persamaan regresi linier data panel bahwa struktur kepemilikan memiliki hubungan nonlinier dengan nilai perusahaan. Hal ini memiliki arti bahwa hubungan antara SK-NP memiliki tidak hanya satu arah hubungan. Hasil penelitian ini tidak sejalan dengan teori rujukan yaitu teori keagenan dengan mempertimbangan hipotesis konvergensi kepentingan dan hipotesis management entrenchment. Dalam penelitian ini, hipotesis konvergensi kepentingan berlaku pada kepemilikan manajerial sebesar 5\%-25\%. Sedangkan, hipotesis management entrenchment berlaku pada kepemilikan manajerial sebesar $\leq 5 \%$ serta kepemilikan manajerial > $25 \%$. Dalam penelitian nonlinier monotonik, seharusnya pengujian dilakukan dengan melakukan trial and error sampai akhirnya menemukan presentase kepemilikan manajerial yang sesuai dengan arah hubungan berdasarkan teori (Chen et al., 2004). Jika kita berdasar pada level kepemilikan manajerial menurut Setiono (2000) maka ada sedikit perbedaan dengan level kepemilikan manajerial menurut Morck et al. (1988). Begitu pula menurut Baker et al. (2012) yang menyatakan bahwa jika ingin mempunyai pengaruh dalam penentuan kebijakan dan keputusan pada RUPS yaitu harus memiliki saham minimal $20 \%$. Sehingga, trial and error dapat dilakukan berdasarkan pada level kepemilikan manajerial menurut beberapa ahli dan penelitian terdahulu.

Berdasarkan hasil uji keberartian koefisien regresi menyatakan bahwa struktur kepemilikan $\leq 5 \%$ dan struktur kepemilikan $>25 \%$ berpengaruh negatif tidak signifikan terhadap nilai perusahaan. Hubbard \& Palia (1995) mengatakan bahwa pengendalian perusahaan mempengaruhi hubungan antara struktur kepemilikan dan return saham perusahaan. Kepemilikan manajerial lebih efektif dalam mengurangi konflik lembaga di daerah pedesaan dengan tingkat asimetri informasi yang lebih tinggi dan tingkat konstituen lokal yang lebih rendah (Benson et al., 2019). Sama seperti CSR-NP, hubungan SK-NP di Indonesia memiliki pola yang sama dengan penelitian yang berada di beberapa Negara lainnya yaitu, bahwa penelitian terkait hubungan SK-NP dipengaruhi oleh variabel moderasi dan/atau intervening. Oleh karena itu, kita tidak dapat mengabaikan variabel tersebut dalam penelitian SK-NP.

Hasil penelitian ini mendukung penelitian McConnell \& Servaes (1990) dengan periode tahun penelitian 1976 dan 1986 pada perusahaan di Bursa Efek Amerika (AMEX), Hermalin \& Weisbach (1991) dengan periode tahun penelitian 1971-1983 pada perusahaan di AMEX, Hubbard \& Palia (1995) dengan periode tahun penelitian 1985 dan 1991 pada perusahaan di Amerika, Holderness et al. (1999) dengan periode tahun penelitian 1935 dan 1995 pada perusahaan di AMEX, Benson \& Davidson (2009) dengan periode tahun penelitian 1995-2003 pada perusahaan yang termasuk kedalam database Standard and Poor's Execucomp, serta Coles et al. (2012) dengan periode tahun penelitian 1993-2000 pada perusahaan yang termasuk dari database Execucomp. Namun, hasil penelitian ini berbeda dengan penelitian Mehran (1995) dengan periode tahun penelitian 19731983 pada perusahaan di Amerika Serikat, penelitian Adams \& Santos (2006) pada bank-bank anggota Federal Reserve System tahun 1962, serta penelitian Pukthuanthong et al. (2007) pada perusahaan AS yang terdaftar di NYSE, AMEX atau NASDAQ tahun 1997-1999 yang menemukan korelasi positif antara struktur kepemilikan dan kinerja perusahaan. Selanjutnya, penelitian Tong (2008) pada perusahaan yang tersedia di Execucomp tahun 1995-2000, menemukan hasil negatif. Sedangkan, penelitian lainnya tidak menemukan hubungan antara struktur kepemilikan dan kinerja perusahaan, yaitu Lodder \& Martin (1997) dengan periode tahun penelitian 1978-1988 pada perusahaan di Amerika Serikat, Himmelberg et al. (1999) dengan periode tahun penelitian 1982-1984 pada perusahaan Compustat, Demsetz \& Villalonga (2001) dengan periode tahun penelitian 1976-1980 pada perusahaan dari semua sektor AS, serta Cheung \& Wei (2006) dengan periode tahun penelitian 1991-2000 yang menggunakan data pasar saham AS. 


\section{Kesimpulan}

Merujuk pada hasil analisis data, pengujian hipotesis, pembahasan, dan temuan penelitian, dapat ditarik simpulan penelitian bahwa CSR berpengaruh tidak signifikan terhadap nilai perusahaan pada perusahaan industri dasar dan kimia Non-BUMN di BEl. Selain itu, struktur kepemilikan berpengaruh nonlinier terhadap nilai perusahaan pada perusahaan industri dasar dan kimia Non-BUMN di BEI. Pengaruh nonlinier tersebut berbentuk $U$ terbalik, yaitu struktur kepemilikan $\leq 5 \%$ berpengaruh negatif tidak signifikan terhadap nilai perusahaan, struktur kepemilikan 5\%-25\% berpengaruh positif signifikan terhadap nilai perusahaan, struktur kepemilikan > $25 \%$ berpengaruh negatif tidak signifikan terhadap nilai perusahaan.

Rekomendasi yang dapat diajukan dari hasil penelitian ini adalah penelitian CSR dan struktur kepemilikan terhadap nilai perusahaan tidak dapat mengabaikan variabel lain yang berpengaruh untuk arah hubungan, kekuatan hubungan, bahkan variabel lain yang harus dilalui oleh hubungan tersebut. Selain itu, terkhusus untuk penelitian nonlinier monotonik pengujian seharusnya dilakukan dengan melakukan trial and error hingga mendapatkan arah hubungan yang sesuai dengan teori serta berdasarkan penelitian terdahulu. Terakhir, memperluas penelitian dengan tidak hanya mempertimbangkan faktor internal kedalam model penelitian nilai perusahaan. Namun, penelitian selanjutnya harus mempertimbangkan faktor eksternal lain yang mempengaruhi nilai perusahaan misalnya pertumbuhan ekonomi, inflasi, serta kondisi moneter. Sehingga diharapkan model lebih prediktif dalam berbagai situasi ekonomi yang terjadi.

\section{Daftar Pustaka}

Abbott, L. J., Peters, G. F., \& Raghunandan, K. (2003). An empirical investigation of audit fees, non-audit fees, and audit committees. Contemporary Accounting Research, 20(2), 215-234.

Adams, R., \& Santos, J. (2006). Identifying the effect of managerial control on firm performance. Journal of Accounting, 41, 55-85.

Allayannis, G., \& Weston, J. P. (2001). The use of foreign currency derivatives and firm market value. Review Finance Study, 14, 243-276.

Baker, H., Kent, \& Chinloy, P. (2012). Public Real Estate Markets and Investments. New York: Oxford University Press.

Benson, B. W., \& Davidson, W. N. (2009). Reexamining the Managerial Ownership Effect on Firm Value. Journal of Corporate Finance, 15(5), 573-586.

Benson, B. W., Chen, Y., James, H. L., \& Park, J. C. (2019). So far away from me: Firm location and the managerial ownership effect on firm value. Journal of Corporate Finance, 64, 101658. https://doi.org/10.1016/j.jcorpfin.2020.101658.

Berk, J., DeMarzo, P., \& Harford, J. (2012). Fundamentals of Corporate Finance. United States of America: Pearson Education.

Bhandari, A., \& Javakhadze, D. (2017). Corporate social responsibility and capital allocation efficiency. Journal of Corporate Finance, 43, 354-377.

Boyer, B., Mitton, T., \& Vorkink, K. (2009). Expected idiosyncratic skewness. Review Finance Study, 23, 169202.

Buchanan, B., Cao, C. X., \& Chen, C. (2018). Corporate social responsibility, firm value, and influential institutional ownership. Journal of Corporate Finance, 52, 73-95. https://doi.org/10.1016/j.jcorpfin.2018.07.004.

Chang, K., Shim, H., \& Yi, T. D. (2019). Corporate social responsibility, media freedom, and firm value. Finance Research Letters, 30, 1-7. https://doi.org/10.1016/j.frl.2019.03.019.

Chariri, A., \& Ghozali, I. (2007). Teori Akuntansi. Semarang: Badan Penerbit Universitas Diponegoro.

Chen, S. S., Ho, K. W., Lee, C. F., \& Shrestha, K. (2004). Nonlinear models in corporate finance research: Review, critique, and extensions. Review of Quantitative Finance and Accounting, 22, 141-169.

Cheung, A., \& Wei, J. (2006). Insider ownership and corporate performance: Evidence from the adjustment cost approach. Journal of Corporate Finance, 12, 906-925.

Coles J., Lemmon, M., \& Meschke, F. (2012). Structural models and endogeneity in corporate finance: The link between managerial ownership and corporate performance. Journal of Financial, 103, 149-168. 
Conrad, J., Dittmar, R. F., \& Ghysels, E. (2013). Ex ante skewness and expected stock returns. Journal Finance, $68,85-124$.

Cronqvist, H., Heyman, F., Nilsson, M., Svaleryd, H., \& Vlachos, J. (2009). Do entrenched managers pay their workers more? Journal of Finance, 64, 309-339.

Davies, J. R., Hillier, D., \& McColgan, P. (2005). Ownership structure, managerial behavior and corporate value. Journal of Corporate Finance, 11(4), 645-660.

Demsetz, H., \& Villalonga, B. (2001). Ownership structure and corporate performance. Journal of Corporate Finance, 7, 209-233.

Desender, K. A., Aguilera, R. V., Crespi, R., \& Garcla-cestona, M. (2013). When does ownership matter? Board characteristics and behavior. Strategic Management Journal, 34(7), 823-842.

Fan, P. H., \& Wong, T. J. (2002). Corporate ownership structure and the informativeness of accounting earnings in East Asia. Journal of Accounting and Economics, 33(3), 401-425.

Friedman, M. (1970). The social responsibility of business is to increase its profits. New York Times Magazine, $13,122-126$.

Friedman, M. (1998). The social responsibility of business is to increase its profits. In: Pincus, L. B. (Eds.) Perspectives in Business Ethics, McGraw- Hill, Singapore, 246-251.

Garcia-Castro, R., Ariño, M. A., \& Canela, M. A. (2010). Does social performance really lead to financial performance? Accounting for endogeneity. Journal of Business Ethics, 92(1), 107-126.

Godfrey, P. C., Merrill, C. B., \& Hansen, J. M. (2009). The relationship between corporate social responsibility and shareholder value: an empirical test of the risk management hypothesis. Strategy Management Journal, $30,425-445$.

Gujarati, D., \& Porter, D. (2009). Dasar-Dasar Ekonometrika. Jakarta: Salemba Empat.

Harmono. (2011). Manajemen Keuangan Berbasis Balanced Scorecard Pendekatan Teori, Kasus, dan Riset Bisnis. Jakarta: Bumi Aksara.

Haugen, R., \& Senbet, L. (1981). Resolving the agency problems of external capital through options. The Journal of Finance, 36, 629-47.

Hermalin, B., \& Weisbach, M. (1991). The effect of board composition and direct incentives on firm performance. Financial Management, 20, 101-112.

Himmelberg, C. P., Hubbard, R. G., \& Palia, D. (1999). Understanding the determinants of managerial ownership and the link between ownership and performance. Journal of Financial Economics, 53(3), 353-384.

Ho, S. S. M., \& Wong, K. S. (2001). A study of the relationship between corporate governance structures and the extent of voluntary disclosure. Journal of International Accounting Auditing and Taxation, 10(2), 139-156.

Holderness, C. G., Kroszner, R. S., \& Sheehan, D. P. (1999). Were the good old days that good? Changes in managerial stock ownership since the great depression. The Journal of Finance, 54(2), 435-469.

Hubbard, G., \& Palia, D. (1995). Benefits of control, managerial ownership, and the stock returns of acquiring firms. Journal of Economics, 26, 782-792.

Husnan, S., \& Pudjiastuti, E. (2012). Dasar-Dasar Manajemen Keuangan (Edisi Ke-6). Yogyakarta: UPP STIM YPKN.

Jensen M., \& Meckling, W. H. (1976). Theory of the firm: managerial behavior, agency costs and ownership structure. Journal of Financial Economics, 3, 305-360.

Jensen, M. (1986). Agency costs of free cash flow, corporate finance, and takeovers. American Economic Review, 76, 323-329.

Keown, Martin, Petty, \& JR. (2010). Manajemen Keuangan: Prinsip dan Penerapan. Jakarta: PT Indeks.

Kole, S. R. (1995). Measuring managerial equity ownership: A comparison of sources of ownership data. Journal of Corporate Finance, 1, 413-435.

Larcker, D. F., \& Richardson, S. A. (2004). Fees paid to audit firms, accrual choices, and corporate governance. Journal of Accounting Research, 42(3), 625-658.

Lodder, C., \& Martin, K. (1997). Executive stock ownership and performance tracking faint traces. Journal of Financial Economics, 45, 223-256.

Margaretha, F. (2011). Teori dan Aplikasi Manajemen Keuangan Investasi dan Sumber Dana Jangka Pendek. Jakarta: Grasindo Gramedia Widiasarana Indonesia.

McConnell, J. J., \& Servaes, H. (1990). Additional evidence on equity ownership and corporate value. Journal of Financial Economics, 27(2), 595-612.

McWilliams, A., \& Siegel, D. S. (2000). Corporate social responsibility and financial performance: correlation or misspecification? Strategic Management Journal, 21, 603-609. 
McWilliams, A., Siegel, D. S., \& Wright, P. M. (2006). Corporate social responsibility: strategic implications. Journal of Management Studies, 43(1), 1-18.

Mehran, H. (1995). Executive compensation structure, ownership, and firm performance. Journal of Financial Economics, 38, 163-184.

Miguel, A. D., Pindado, J., \& Torre, C. D. L. (2004). Ownership structure and firm value: New evidence from Spain. Strategic Management Journal, 25(12), 1199.

Morck, R., Shleifer, A., \& Vishny, R. W. (1988). Management ownership and market valuation: An empirican analysis. Journal of Financial Economics, 20, 293-315.

Myers, S. (1977). The determinants of corporate borrowing. Journal of Financial Economics, 5, 147-175.

O'Sullivan, N. (2000). The impact of board composition and ownership on audit quality: Evidence from large UK companies. The British Accounting Review, 32(4), 397-414.

Orlitzky, M., Schmidt, F. L., \& Rynes, S. L. (2003). Corporate social and financial performance: A meta-analysis. Organization Science, 24(3), 403-441.

Pagano, M., \& Volpin, P. F. (2005). Managers, workers, and corporate control. Journal of Finance, 60, 841-868.

Pérez-González, F. \& Yun, H. (2013). Risk management and firm value: evidence from weather derivatives. Journal Finance, 68, 2143-2176.

Pukthuanthong, K., Roll, R., \& Walker, T. (2007). How employee stock options and executive equity ownership affect long-term IPO operating performance. Journal of Corporate Finance, 13, 695-720.

Rahmawati, A., Pramasterina, B. H., \& Setiawan, D. (2020). Analisis metode penelitian pada bidang CSR di Indonesia. Jurnal Aplikasi Manajemen dan Bisnis, 6(2), 242-257.

Rjiba, H., Jahmane, A., \& Abid, I. (2020). Corporate social responsibility and firm value: Guiding through economic policy uncertainty. Finance Research Letters.

Schleifer, A., \& Vishny, R. W. (1997). A survey of corporate governance. The Journal of Finance, 52(2), 737-783.

Schooley, D. K., \& Barney, L. D. (1994). Using dividend policy and managerial ownership to reduce agency costs. The Journal of Financial Research, 17(3), 363-373.

Sheikh, S. (2018). Corporate social responsibility, product market competition, and firm value. Journal of Economics and Business, 98, 40-55. https://doi.org/10.1016/j.jeconbus.2018.07.001.

Short, H., \& Keasey, K. (1999). Managerial ownership and the performance of firms: Evidence from the UK. Journal of Corporate Finance, 5(1), 79-101.

Sudarma, I. K. G. A. M., \& Darmayanti, N. P. A. (2017). Pengaruh CSR, Kepemilikan Manajerial dan Profitabilitas Terhadap Nilai Perusahaan Sektor Pertambangan Pada Indeks Kompas 100. E-Jurnal Manajemen Unud, Vol 6 (4), 1906-1932.

Tong, Z. (2008). Deviations from optimal CEO ownership and firm value. Journal of Banking \& Finance, 1-19.

Van, B. P., \& Gossling, T. (2008). The worth of values - A literature review on the relation between corporate social and financial performance. Journal of Business Ethics, 82 (2), 407- 424.

Zolotoy, L., O'Sullivana, D., \& Chen, Y. (2019). Local religious norms, corporate social responsibility, and firm value. Journal of Banking and Finance, 218-233. https://doi.org/10.1016/j.jbankfin.2019.01.015. 